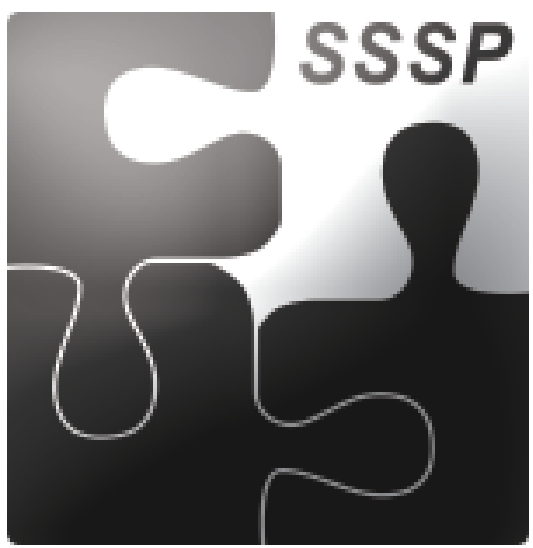

Gender Inequality and the Division of Household Labor in the United States and Sweden: A Socialist-Feminist Approach

Author(s): Toni M. Calasanti and Carol A. Bailey

Source: Social Problems, Vol. 38, No. 1 (Feb., 1991), pp. 34-53

Published by: University of California Press on behalf of the Society for the Study of Social

Problems

Stable URL: http://www.jstor.org/stable/800637

Accessed: 19/02/2014 09:12

Your use of the JSTOR archive indicates your acceptance of the Terms \& Conditions of Use, available at http://www.jstor.org/page/info/about/policies/terms.jsp

JSTOR is a not-for-profit service that helps scholars, researchers, and students discover, use, and build upon a wide range of content in a trusted digital archive. We use information technology and tools to increase productivity and facilitate new forms of scholarship. For more information about JSTOR, please contact support@jstor.org. 


\title{
Gender Inequality and the Division of Household Labor in the United States and Sweden: A Socialist-Feminist Approach*
}

\author{
TONI M. CALASANTI, Virginia Polytechnic Institute and State University
}

CAROL A. BAILEY, Virginia Polytechnic Institute and State University

\begin{abstract}
In this paper, we offer a socialist-feminist framework for exploring the persistence of gender inequality in the disvision of household labor. The inconsistent results generated by the relative resources, gender-role ideology, and time-availability hypotheses speak to the need to examine the structural bases for power relations based on gender. Emphasizing the relative autonomy and interrelations of capitalism and patriarchy, socialist-feminism posits that different forms of patriarchal capitalism have varying effects on the division of household labor. (We thus examine the usefulness of this approach by exploring the relationships expressed in three traditional hypotheses about gender inequality and the performance of five household tasks in the United States and Sweden.) The results of our regression analyses indicate that previous perspectives do not adequately examine the power differential embodied in gender relations and that socialist-feminism may give us insights into why gender inequities in the home are maintained despite progressive legislation.
\end{abstract}

\section{Introduction}

Gender inequality in the division of household labor entails important economic and social-psychological consequences for women. Constraints imposed by child care and housework influence the jobs women obtain, the hours they work, and the pay they receive (Kalleberg and Rosenfeld 1990; Coverman 1989; 1983; Shelton and Firestone 1988; Reskin and Hartmann 1986). Further, employed women, and not men, experience an "over-burden" of domestic labor to the detriment of their psychological well-being (Coverman 1989; Moen 1989).

Both the basis for and the pervasiveness of this division of labor have been researched extensively in recent years, especially in light of the increased number of wives employed full-time (Bielby and Bielby 1989). These studies have tested a number of explanations, generally focusing on the relative resources and power available to spouses, the gender-role ideology of spouses, and the time available to meet the demands made at home and at work (Coverman 1985; Ross 1987; Seccombe 1986). Research findings are mixed and do not point to one explanation as better than others. Further, any single approach seems inadequate for explaining the gendered division of labor within the home (Finley 1989; Perry-Jenkins and Crouter 1990).

In this paper we adopt a socialist-feminist framework to examine the division of household labor. Use of this perspective is a response to the perceived inability of prior approaches to deal with the issue of gender relations, and the power embodied therein, in a structural

* We would like to express our appreciation to Anna Zajicek, John Edwards, Peter Laws, and Ellsworth R. Fuhrman for thoughtful comments on earlier drafts of this manuscript, and Phyllis Light for secretarial support. Correspondence to: Calasanti, Department of Sociology, Virginia Polytechnic Institute and State University, Blacksburg. VA 24061 
way. From a socialist-feminist approach, we draw the notion that gender inequality stems from the intersection of capitalism and patriarchy. The purpose of this paper is to test the relevance of socialist-feminism for understanding the gender division of labor by comparing the three general hypotheses within two countries which have different forms of patriarchal capitalism, specifically Sweden and the United States. Given this structural variation, we anticipate that the variables which explain the division of domestic labor will differ across countries. At the same time, given that none of these three models capture the structural basis of gender relations, we expect gender to be the most important variable for predicting household task allocation in both countries.

\section{Who Performs Domestic Labor, and Has This Changed?}

Research from the 1960s through the 1980s show that men average about 11 hours a week in domestic labor. ${ }^{1}$ Women not employed outside the home, on the other hand, average just over fifty hours a week; employed wives spend 26 to 33 hours (Coverman 1989; Coverman and Sheley 1986). Wives are responsible for between 70 percent to 92 percent of domestic labor, with 75 percent being the average (Coverman 1989; Berardo, Shehan and Leslie 1987: Ross 1987; Berheide 1984).

In noting women's labor force status and a slight reduction in their home labor, many assume that there is an "increasing convergence of sex roles." However, studies indicate that the increased labor force participation of women has not led to a substantial change in home labor (Bielby and Bielby 1989; Spitze 1988; Coverman and Sheley 1986; Kilty and Richardson 1985), despite some husbands' perceptions that they are participating more (Hiller and Philliber 1986). For the most part, findings range from no change in men's contribution to an increase of 26 minutes a day (Shelton 1990; Coverman 1985; Berheide 1984).

Furthermore, Hartmann (1981) reports that married women with children spend more time in domestic labor than single mothers with the same number of children. Similarly, Kilty and Richardson (1985) found when comparing across marital statuses that the largest difference between men and women in time spent on domestic labor was for those who are currently married. Thus, as Hartmann (1981:383) suggests, "husbands may require more housework than they contribute".

In short, it appears that "the practical impact of [any increase in men's] contribution is limited" (Berk 1989:295) and does not portend future trends (Coverman and Sheley 1986). If role-sharing is the issue, "women are sharing the provider role to a greater extent than men are sharing family work" (Voydanoff 1988:277).

\section{Hypotheses and Research on the Division of Labor}

\section{Hypotheses}

Several competing explanations of the division of domestic labor have been offered. While the names may vary across studies (Coleman 1988), we cluster the most commonly used approaches into three alternative hypotheses.

1. According to the relative resources approach, domestic labor is allocated based on the power of each spouse (Ross 1987). This approach assumes that the spouse with the most power will partake in fewer unpleasant tasks; childcare and housework are assumed to be among these (Seccombe 1986). Power, in turn, is assumed to be related to possession of social

1. Four activities can be considered as household labor: housework, childcare, support work, and status production (Coverman 1989: 357). In this review, we confine our comments to housework and child care. 
resources (Perry-Jenkins and Crouter 1990; Coverman 1985). Thus, for example, the power of wives rests on their relative contributions to family income (Hood 1983). Social resources are generally examined by looking at spouses' educational level, occupational type and prestige, and a couples' earnings ratio (Coverman 1989). In general, the greater a man's education and occupational prestige relative to his wife's, the less he will participate in domestic labor (Coverman 1985).

2. The gender-role ideology hypothesis states that household tasks are allocated on the basis of gender attitudes and values learned through socialization (Finley 1989; Berardo, Shehan, and Leslie 1987). Thus, if both spouses work for pay but also believe that the woman should be responsible for housework, they may still define household chores as hers to do. Less traditional beliefs, on the other hand, lead to a more equal division of labor within the home (Ross 1987). This explanation assumes that gender-role ideology is related to education and occupational prestige. Those persons with higher levels of schooling and occupational prestige are expected to have more egalitarian attitudes.

3. Finally, the time-availability hypothesis suggests that the domestic division of labor is based on rational considerations of who has the most time to do household tasks. While similar to the resource approach, it assumes that decisions about market labor occur before domestic labor decisions (Spitze 1988:600). Thus, "relative time in market work is affected by relative potential wages, and in turn the remaining hours of each spouse are allocated, in relative proportion, to home work" (Spitze 1986:691). The person who has more time at home will perform more domestic tasks; if husbands and wives are employed an equal number of hours, they should both perform equal amounts of domestic labor (Ross 1987).

Coverman (1985) refined this approach to relate more clearly to husbands' participation in household labor. The "demand/response" focus of the time-availability hypothesis goes beyond a consideration of a wife's work hours and views a man's participation in domestic labor as a function of two things. The first is the level of demands placed on him; this can be measured by number of children and spouse's employment status. The second is his ability to respond to these demands, ascertained by examining such things as number of hours spent in paid labor. In addition, absolute level of earnings is important as it may reflect the ability to pay for either labor-saving devices or for the services of others to engage in household tasks.

\section{Critique}

Each of these approaches can be criticized on two general grounds. Below we discuss each hypothesis in terms of empirical support, ending with a general critique from a socialistfeminist perspective.

Relative resources hypothesis. The research support for the effect of relative power as measured by the difference in husbands' and wives' earnings is mixed. Some studies show that the greater the difference in favor of the husband's paycheck, the less housework he did (Ross 1987), while others do not find support for this prediction (Coverman 1985; Spitze 1988). Similar mixed results are found when controlling for class and occupational prestige of the couples (Ferree 1987; Berardo, Shehan and Leslie 1987; Seccombe 1986; Hartmann 1981). Again, while it does appear men participate more in domestic tasks when their wives become employed, the actual increase is quite small. Indeed, a husband's relative share of domestic labor may increase when his wife works but only because she decreases the amount she does (Coverman 1989; Pleck 1984). Thus, while a wife's decision-making power may increase in proportion to her income contribution, her ability to redistribute household tasks does not (Spitze 1986).

Findings for education also do not support this hypothesis, as increased education has been associated with higher levels of men's participation (Farkas 1976). The influence of 
occupation appears more mixed, ranging from positive to curvilinear to no relationship (Coverman 1985).

On a theoretical level, this perspective is incomplete on these grounds: it does not clearly state how resources translate into power in the marital dyad (Coverman 1985); it assumes that a women's lack of income alone leads to the present division of labor; and it never questions why income should be associated with power. Both empirically and theoretically, then, this perspective appears to be wanting.

Gender-role ideology. Research addressing the importance of gender-role ideology on the household division of labor has produced inconsistent findings. In general, it appears that, where there is an effect, it is the husband's ideology which matters; a wife's attitude has no influence (Finley 1989; Ross 1987; Seccombe 1986). ${ }^{2}$ However, the direction and extent of this effect is variable. Some research has found that husbands with traditional gender-role values contribute less to household tasks and those with less traditional values participate more (Ross 1987; Seccombe 1986). In contrast, others have found that a more egalitarian ideology either had no effect on husbands' contributions (Coverman 1989) or it "slightly decreased the domestic labor time of married men" (Coverman 1985:94).

Findings for education also present problems for the gender-role hypothesis as the relationships are not as predicted. The finding of no influence for education (Spitze 1986; Kilty and Richardson 1985) contradicts the theoretical assertion that more educated men and women will be less traditional. Kilty and Richardson (1985:180-81) maintain, "Education may well simply perpetuate traditional sex role conceptions. After all, the purpose of socialization is to pass on cultural traditions and values." As the educational system tends to be both traditional and male-dominated, it likely reinforces the unequal power relation already existent in present gender-role patterns.

The gender-role ideology hypothesis also ignores other aspects of gender relations which would perpetuate male domination. For example, research shows that husbands believe traditional gender roles are innate more than do wives, allowing them to justify their advantaged social position and reinforcing the greater power men hold in the relationships. Similarly, the power differential reflected in the finding that husbands' ideology is more important than wives' is not explained by this approach. Finally, such issues as where ideology comes from, what purposes it serves, and who benefits from it are never explicitly addressed by the gender-role ideology hypothesis. Thus, this approach cannot provide a complete understanding of gender inequality in the household division of labor.

Time-availability. As noted above, contrary to the time-availability hypothesis, most studies find that a woman's employment status does not significantly influence the gender division of labor (Spitze 1988; Pleck 1977). This holds true regardless of wives' type of job since career women do not differ significantly from other full-time employed wives in hours of housework performed weekly (Berardo, Shehan and Leslie 1987). A more precise test of the effects of wives' availability is the number of hours a woman works. Generally, a wife's work hours decreases the time she spends in household tasks (Coverman 1989). However, with the exception of one study (Spitze 1986), wives' number of hours worked has virtually no effect on husbands' participation in household labor (Rexroat and Shehan 1987), contrary to what the time-availability hypothesis would predict.

While it might be argued that husbands' work hours are of greater significance than wives' in explaining domestic labor patterns, findings on the influence of husbands' hours also have been mixed (Spitze 1988). Some studies have found a significant relationship between men's work hours and time spent on domestic labor, although these contributions are still low

2. There is an exception, however. One recent study did find that a wife's ideology was not only important but even more influencial than her husband's (Hardesty and Bokemeier 1989). 
(Coverman 1985; Rexroat and Shehan 1987). On the other hand, contrary to the assumption that the major reason men do not do more is lack of time, Coverman and Sheley (1986:420) found that while men's work time decreased over a ten-year period, they used their increased "free" time in leisure pursuits, not housework. Similarly, with increased demands, such as the addition of children, the husband's contribution to household tasks did not significantly rise. Even if the wife is working, the home is still considered her responsibility: "couples take time constraints into account, but they do not take them very far" (Ross 1987:826).

Similar to the other approaches, the time-availability hypothesis ignores the historical and contextual basis of power. For example, it has been maintained that the division of labor in the past was economically rational because women were at home and could perform the more time-consuming tasks (Ross 1987). This takes the past pattern for granted, as nonproblematic: if that is the way it was, and it "worked," it must have been rational. The rationality argument is further weakened in light of current evidence which indicates that full-time employed women still perform the majority of household tasks. The question becomes, rational for whom? Rather than being based solely on rationality, "social and cultural definitions of what is considered right and who has power" play an important role in the allocation of household tasks (Ross 1987:830). Thus, "rather than reformulating variations of these theories on the individual level to provide 'better' measures of variables such as power, time available, and so on, we must turn to the structural nature of gender differences" (Finley 1989:85).

\section{The Need for a New Approach}

Given the research performed in the United States, it does not appear that the division of domestic labor is simply due to economic and attitudinal issues. Husbands of women with "greater economic power"-a paid job-do not necessarily share domestic tasks more. Women with egalitarian attitudes or whose husbands have them are not necessarily relieved of domestic duties, nor do flexible work hours or increased household burdens insure that husbands will engage in more domestic labor. None of the hypotheses accounts for why women engage in a disproportionate share of domestic tasks "regardless of the time available, the attitudes of obligation, or the external resources" (Finley 1989:84).

What appears to be lacking from previous approaches is an explicit consideration of gender stratification (Coleman 1988): the way in which gender itself embodies a power relationship in both public and private spheres. In this sense, gender has not been included as a crucial variable. Education, income, and other variables which may vary by gender have been explored. However, these factors, important in the public sphere, are assumed to translate directly into the family setting. The fact that gender relations at home have their own dynamic which mediates between these factors and the actual organization of domestic activities is ignored. As Spitze (1986:698) notes, "It is difficult to speak of power in the context of an individual household without taking into account the societal context of women's lower status." This is what socialist-feminism advocates: examining gender relations as these operate in relatively autonomous yet interrelated spheres of social life.

\section{Toward a Socialist-Feminist Approach}

Building on the work of Hartmann (1981), socialist-feminism ${ }^{3}$ hypothesizes that both capitalism and patriarchy are responsible for the present division of labor. Beginning from a

3. We include under socialist-feminism several approaches, some of which are referred to as Marxist-feminism. The distinction between these two strands of feminist theory rests on their treatment of the primacy of capitalism and patriarchy in explaining women's status. We include under our nomenclature those theorists who give equal weight to both systems. 
view of gender as "structural, relational, and symbolic differentiations between women and men" (Acker 1989: 238), this perspective posits that men historically have controlled women's home labor through the gender division of labor. Under capitalism, patriarchy expanded from the private sphere into the public. We see this in contemporary society wherein men dominate women in both realms. This historical process, as Hartmann argues, can be explained by conceiving of patriarchy and capitalism as analytically separate but interrelated realms of social oppression (Sokoloff 1988).

As an example, when women entered the labor market at the end of the eighteenth century, male workers, resistant to competition, often combined with capitalists to segregate women occupationally and depress their wages. The "family wage" paid to men became a powerful argument to push women back into the home. As a result, women became relegated to the domestic sphere, economically dependent upon men and dialectically reinforcing men's superiority. Now, women working outside the home are subjected to a "'double day' of wage work and housework" (Hartmann 1981:386). The domestic division of labor is thus rooted in the historical transformations of capitalism and patriarchy which set the context of people's private and public lives and ideologically define "women's place" at home. The inadequacy of present explanations of the division of domestic labor lies in their omission of the linkages between local and general, between social relations at home and in the society at large.

The socialist-feminist approach posits that patriarchy within the household cannot be merely relegated to attitudes about who ought to perform which task (Lengermann and Niebrugge-Brantley 1988:425). Instead, we must look at the interplays of social relations of production and reproduction with respect to gender, asking who controls women's labor and benefits from it. Moreover, the socialist-feminist approach also points to the need to take care in making unconditional assertions about the relations between private and public spheres. That is, changes in the society at large do not necessarily presage changes in the household; family relations have their own dynamic and relative autonomy. The growing participation of women in the labor force or state policies which aim at levelling structural differentiations between women and men in the public sphere may result in greater equality in the domestic division of labor (Hardesty and Bokemeier 1989), but this connection is by no means necessary.

In contrast to other perspectives which have ignored gender relations, for the most part, socialist-feminism assumes that if patriarchy exists as "a system of social structures and practices in which men dominate, oppress, and exploit women" (Walby 1989:214), gender will play an important role in determining who performs household labor. Gender, then, might become a key commonality across countries even within diverse socio-economic systems. At the same time, examining gender is not sufficient, for gender relations occur within a concrete social context; differences in the economic, political, and ideological aspects of social organization may be reflected in social patterns of interpersonal relationships. Thus, socialist-feminists would expect the form of patriarchal capitalism to result in variations in the determinants of the division of domestic labor between countries.

We propose to further our understanding of the gender division of domestic labor by using socialist-feminism to examine the social context of gender relations. To do so requires variation in the dynamics of patriarchy and capitalism. This is accomplished by comparing two capitalist countries, the United States and Sweden, which differ in the polity and ideology of patriarchy as expressed in state policies related to work and family. As patriarchal capitalism exists in both countries, we would expect similarities between these nations in terms of the importance of gender for explaining the divisions of domestic labor. At the same time, based upon the structural variation in state policies, we could expect variations in other predictors of the division of household labor across these countries. 


\section{Patriarchal Capitalism and State Policies in the United States and Sweden}

It is widely acknowledged that in the United States the means of production are privately owned. Patriarchy both at home and at work is readily seen in such things as the high level of occupational segregation (Reskin and Hartmann 1986), women's responsibility for domestic labor, and unequal pay for equal or comparable work.

Sweden's economic system is not radically different from the United States in that 85 percent of industry is privately owned (Sidel 1986). However, the two countries do vary in terms of the form of patriarchal capitalism. In this regard, Sweden has a far more developed welfare state than the United States. While both countries experienced the economic depression of the 1930s, the economic and social policies, which signalled the increased role of the state, were far more pronounced in Sweden, leading to its designation as "the prototype of the social welfare state" (Sidel 1986:185). The divergence of such state policies in Sweden and the United States presents a different context for gender relations within the two countries. Thus, while gender will be of importance in both nations, its effects will vary.

In terms of the present interest, Sweden enacted a number of family policies in the wake of a declining post-depression birth rate. In addition, during the 1960 s several policies were passed in an attempt to equalize gender roles (Sidel 1986; Haas 1981:957). These policies include changes in tax laws and government subsidies for families, government support for daycare centers, and comparable worth laws. Liberal parental and sick leave policies allow either parent time off to care for children, and flexible work schedules enable parents to reduce their time at work to six hours a day for child care purposes. Elementary schools teach child care and homemaking skills to students of both genders, stressing the responsibility of both parents (see Sidel 1986 and Haas 1981 for a more complete summary of these policies).

While these policies have had important effects, they have not led to gender equality. In terms of the labor force, 86 percent of mothers of preschool-aged children were in the work force in 1986. Yet 60 percent of these mothers worked less than thirty-five hours a week, in contrast to only 4 percent of fathers (Moen 1989; Hoem and Hoem 1988; Sidel 1986:178). Less than one-third of the fathers take parental leave, and only 2 percent of fathers of preschoolers take advantage of flexible work schedules to engage more actively in child care (Hoem and Hoem 1988; Sidel 1986:181-182). Taken together, women avail themselves of flexible work schedules and leaves far more than men (Moen 1989; Hoem and Hoem 1988).

As in the United States, Swedish women still perform the majority of household tasks, particularly when there are children in the home (Moen 1989; Haas 1981). These results suggest that in line with a socialist-feminist framework, patriarchy and capitalism interact but are relatively autonomous. Despite changes in the form of capitalism, patriarchy is still evident in Sweden. Indeed, Haas's (1981) finding that the home is still overwhelmingly the wife's responsibility and that a relatively low percentage of fathers avail themselves of parental leaves indicate that the private sphere is still a Swedish woman's domain. In addition, evidence points to the prevalence of patriarchy within the workforce as women are still highly segregated into thirty job categories which, just as is true of the United States, tend to be low-paid (Sidel 1986). Finally, policy changes have not resulted in a higher value being placed upon domestic labor, as seen in men's fears that availing themselves of parental leave would be viewed negatively by co-workers and employers. As Hoem and Hoem (1988:399) stress, "Gender equality gets interpreted as 'sameness' with men; you cannot be an 'equal' if you are a housewife, no matter what your family obligations entail." Taken together, the family policies in Sweden have allowed women not men to better balance demands in public and private spheres (Kalleberg and Rosenfeld 1990; Moen 1989). 


\section{Hypotheses}

Sweden and the United States differ in forms of patriarchal capitalism, as seen in state policies, while retaining some degree of gender inequality in the allocation of household tasks. Thus, the relevance of socialist-feminism for understanding the gender division of labor can be tested by comparing the three general hypotheses within each country. The expectation here is that given the structural variation in state policies between Sweden and the United States, we should find differences between the ability of the relative resources, gender-role ideology, and time-availability models to account for the domestic division of labor. While we cannot speculate upon the exact nature of these differences, it is expected that they will reflect the variation in state involvement between countries. For example, it might be the case that the relative resource approach would be less crucial in Sweden, where the state's provision of social services might alleviate some of the importance of the economic disparity between men and women.

At the same time, the socialist-feminist perspective would also anticipate similarities between the United States and Sweden based upon the importance of gender. First, if patriarchy structures relationships in the private and public spheres and if, as we maintain, all three hypotheses have ignored this crucial power differential, these approaches will be unable to account for variation due to gender. Second, as both countries are patriarchal, there may be some important similarities between the United States and Sweden in regard to some of the significant predictors which reflect the man's greater ability to negotiate the domestic labor division, such as men's work schedules and men's gender-role ideology.

\section{Method}

\section{Sample}

The data for this analysis are from the Wright (1986) cross-national study, which used a multi-stage sampling procedure to select a sample of non-institutionalized adults. Intensive personal interviews were conducted with the subjects, resulting in a total of 1760 and 1145 cases from the United States and Sweden, respectively (Wright 1986).

In our analysis, we used married individuals living with their spouses. Both husband and wife had to be employed for wages, either by others or self-employed, for at least 21 hours per week to be included in the sample. We circumscribe our sample this way because we are primarily interested in gender division of labor for those couples who both work outside the home, and thus both have substantial demands made on their time outside the home. Using these criteria, we selected 422 married subjects from the United States, 214 women and 208 men. From Sweden we identified 187 women and 296 men, rendering a total of 483 married subjects.

\section{Independent Variables}

Most of the variables are self-explanatory, such as age and education, with only minor modifications between the United States and Sweden. For example, income in the United States was reported in U. S. dollars, and in Sweden it was reported in Swedish crowns.

Our measures of the three hypotheses reflect those found in the literature, mediated by constraints placed by analysis of secondary data.

Relative resources. Our measures of the relative resources hypothesis include the respondent's occupational status as well as that of spouse, respondent's education and, as suggested by Coverman (1985), a measure of the percent of income contributed by the spouse. This 
hypothesis predicts that the higher wives' proportional contribution to overall income, the more husbands engage in domestic labor (Ferree 1987). Similarly, the higher the wife's occupation and education, the more a husband participates in household tasks.

Gender-role ideology. The variable gender-role ideology is a four-item Likert scale consisting of responses reflecting agreement to the following: (1) It is better for the family if the husband is the principal breadwinner outside the home and the wife has primary responsibility for the home and children; (2) If both husband and wife work, they should share equally in housework and child care; (3) There are not enough women in responsible positions in government and business; (4) Ideally, there should be as many women as men in important positions in government and business. The answers to these questions were recoded and summed so that low values on the gender-role ideology scale indicate a "traditional" gender-role ideology while high values indicate an "egalitarian" gender-role ideology. Cronbach's alpha for different sub-groups ranged from .52 to .62 .

Education and occupational status are also predictors of the gender-role approach because of their assumed relationship with egalitarian gender-role attitudes. Thus, according to this hypothesis, the more egalitarian the gender-role attitudes, the more egalitarian the allocation of household labor. Similarly, the higher the educational level and occupational prestige, the more equal the gender division of household labor.

We must also note that the relative resource and gender-ideology hypotheses posit contradictory predictions (Coverman, 1985:83). That is, if the gender-role ideology hypothesis is correct, education and occupational status will increase men's domestic labor. If, on the other hand, relative resources determine how much time men spend in domestic labor, higher education and occupational status will result in less time.

Time availability. Consistent with past research, the time-availability variables included in this study are the number of children, the number of hours worked, and the absolute level of income. This hypothesis predicts that the greater the number of children, the fewer hours worked by a husband, and the lower the income, the greater the man's contribution to domestic labor.

Age. Consistent with past studies, age also is considered. As it relates to the hypotheses above, age would be expected to have a negative effect on an egalitarian division of domestic labor in two of the three models. First, age may relate to gender-role ideology; research has found younger men are more egalitarian. Second, older men generally have higher earnings and occupational prestige. For both reasons, the older the man, the less likely he is to engage in domestic labor. Indeed, a number of studies in both the United States and Sweden have found this relationship between age and household labor among men (Coverman 1985; Haas 1981). By the same token, while age may be important for women's gender-role ideology, it is less likely to influence her occupation and earnings, given labor market discrimination. If we find that only a man's age is significant, it would again indicate the greater importance of the characteristics of men in the division of domestic labor, a finding which would point to the influence of patriarchy.

\section{Dependent Variables}

Five household tasks are used as dependent variables: cooking, doing dishes, doing laundry, cleaning house, and grocery shopping. For each, respondents were asked the following: What percent (of task) is done by you? Each task was analyzed separately, in case the relationships vary by type of task. 


\section{Analysis}

After the descriptive statistics, the five domestic tasks are regressed on age and the variables which make up the three hypotheses. The multiple regressions are performed for each subgroup separately: U. S. men, U. S. women, Swedish men, Swedish women. Then, additional regressions are run on the United States and Sweden separately because of differences in the variables. In this series, the men and women subsamples for a country are combined, and gender is included as an additional dummy variable (coded $0=$ woman, $1=\operatorname{man}$ ). A finding of a significant effect for gender on the dependent variables while controlling for the other variables supports the contention that the power differential which structures relationships in the public and private spheres has not been accounted for by the other hypotheses.

\section{Results}

The means, standard deviations, and t-tests comparing men and women across countries are presented in Table 1 . The differences on the independent variables are consistent with structural variations between the United States and Sweden. Swedish men are more favorable toward gender equality, work fewer hours, and have spouses who contribute more to total income than U.S. men. Differences between U.S. and Swedish women also reflect the more developed nature of welfare capitalism in Sweden: Swedish women work fewer hours and are also more egalitarian in their attitudes than U.S. women. Given the apparent structural differences, it is interesting that Swedish men are significantly more involved than U.S. men in only two household tasks, cooking and cleaning house. Similarly, Swedish women only do less cooking and grocery shopping than U.S. women. While results of $t$-tests for this comparison are not shown in Table l, women do significantly more household tasks than men in both countries. Women in the United States contribute 73 percent to 84 percent of household labor; Swedish women range from 63 percent to 80 percent. It does not appear that the structural changes in Sweden have had a major impact on equalizing the allocation of household tasks, but it is still unclear whether the same factors account for the unequal labor division. However, the fact that significant gender inequality in the division of domestic labor exists in both countries, even while Swedish men do somewhat more than U. S. men indicates the relative autonomy of gender relations at home in the context of different forms of patriarchal capitalism.

At the bivariate level (correlation tables available from the authors), none of the variables is important for all subgroups. The percent of spouse's contribution to family income, genderrole ideology, an individual's income, and hours worked are related to at least two of the five tasks among three subgroups.

\section{United States}

Men. As can be seen in Table 2, the gender-role ideology hypothesis receives the greatest support among men from the United States. It appears that men who have more egalitarian attitudes engage more in a variety of household tasks. Further, men are more likely to be involved in cooking and laundry if their wives contribute more to total income. The influence of education is not significant in the opposite direction from the effects of gender-role ideology. While this may be the case because the gender-role ideology measure already captured the "positive" effects of education, it may also be, as Kilty and Richardson (1985) sug. gest, that the education system serves to reinforce the traditional division of labor through its socializing influence. The variance explained ranges from 8 percent to 18 percent, indicating that even when combined, these models account for little of the domestic division of labor. 
Table 1 - Test of Mean Differences of All Variables Across Countries by Gender

\begin{tabular}{|c|c|c|c|c|c|c|}
\hline & \multicolumn{3}{|c|}{ Men } & \multicolumn{3}{|c|}{ Women } \\
\hline & $\begin{array}{c}U . S . \\
N=208\end{array}$ & $\begin{array}{c}\text { Swedish } \\
N=296\end{array}$ & 2-tailed $t$ & $\begin{array}{c}U . S . \\
N=214\end{array}$ & $\begin{array}{c}\text { Swedish } \\
N=187\end{array}$ & 2-tailed $t$ \\
\hline Age & $\begin{array}{c}38.32 \\
(10.76)^{1}\end{array}$ & $\begin{array}{c}40.95 \\
(10.92)\end{array}$ & $-2.66^{* *}$ & $\begin{array}{c}36.89 \\
(11.41)\end{array}$ & $\begin{array}{c}37.87 \\
(11.21)\end{array}$ & -.86 \\
\hline Spouse Income & $\begin{array}{c}31.85 \\
(18.69)\end{array}$ & $\begin{array}{c}39.62 \\
(18.63)\end{array}$ & $-4.5 l^{* * *}$ & $\begin{array}{c}63.06 \\
(24.28)\end{array}$ & $\begin{array}{c}65.28 \\
(15.47)\end{array}$ & -1.07 \\
\hline Hours Worked & $\begin{array}{c}48.95 \\
(13.57)\end{array}$ & $\begin{array}{l}43.38 \\
(8.33)\end{array}$ & $5.26 * * *$ & $\begin{array}{c}41.09 \\
(10.22)\end{array}$ & $\begin{array}{c}35.39 \\
(7.28)\end{array}$ & $6.50 * * *$ \\
\hline No. of Children & $\begin{array}{c}1.13 \\
(1.19)\end{array}$ & $\begin{array}{l}1.19 \\
(1.05)\end{array}$ & -.56 & $\begin{array}{c}.85 \\
(1.13)\end{array}$ & $\begin{array}{c}.98 \\
(.99)\end{array}$ & -1.21 \\
\hline Gender Ideology & $\begin{array}{l}11.17 \\
(2.42)\end{array}$ & $\begin{array}{l}12.60 \\
(2.55)\end{array}$ & $-6.21 * * *$ & $\begin{array}{l}11.87 \\
(2.37)\end{array}$ & $\begin{array}{l}13.60 \\
(2.15)\end{array}$ & $-7.34 * * *$ \\
\hline Cooking & $\begin{array}{c}22.37 \\
(26.50)\end{array}$ & $\begin{array}{c}27.02 \\
(23.79)\end{array}$ & $-2.03 *$ & $\begin{array}{c}80.32 \\
(26.38)\end{array}$ & $\begin{array}{c}72.86 \\
(23.84)\end{array}$ & $2.90 * *$ \\
\hline Dishes & $\begin{array}{c}29.11 \\
(24.78)\end{array}$ & $\begin{array}{c}24.98 \\
(25.39)\end{array}$ & 1.78 & $\begin{array}{c}73.19 \\
(30.33)\end{array}$ & $\begin{array}{c}72.63 \\
(24.31)\end{array}$ & .20 \\
\hline Laundry & $\begin{array}{c}22.02 \\
(28.01)\end{array}$ & $\begin{array}{c}17.92 \\
(23.28)\end{array}$ & 1.70 & $\begin{array}{c}84.20 \\
(25.72)\end{array}$ & $\begin{array}{c}79.51 \\
(25.78)\end{array}$ & 1.79 \\
\hline House Cleaning & $\begin{array}{c}25.97 \\
(22.61)\end{array}$ & $\begin{array}{c}30.51 \\
(25.40)\end{array}$ & $-2.03 *$ & $\begin{array}{c}73.79 \\
(26.77)\end{array}$ & $\begin{array}{c}69.90 \\
(25.86)\end{array}$ & 1.46 \\
\hline Grocery Shopping & $\begin{array}{c}31.86 \\
(30.94)\end{array}$ & $\begin{array}{c}36.59 \\
(23.36)\end{array}$ & -1.82 & $\begin{array}{c}73.89 \\
(28.37)\end{array}$ & $\begin{array}{c}62.88 \\
(24.02)\end{array}$ & $3.94 * * *$ \\
\hline $\begin{array}{l}\text { Notes: } \\
{ }^{1} \text { Standard deviation } \\
\begin{aligned} * \quad p<.05 \\
{ }^{* *} \quad \mathrm{p}<.01 \\
{ }^{* * *} \mathrm{p}<.001\end{aligned}\end{array}$ & parenthese & & & & & \\
\hline
\end{tabular}

Women. Table 2 shows that in contrast to the men, gender-role ideology is significant for U.S. women on only two of five household tasks: dishes and groceries. On the other hand, the number of hours worked has a strong negative effect on all household tasks. Only two other predictors (income and spouse's income) are statistically significant, but for only one task each. Finally, a relatively small amount of variance is explained by these predictors, from 10 percent to 14 percent.

\section{Sweden}

Comparing across countries provides some support for the socialist-feminist hypothesis as, in general, different sets of factors account for the domestic division of labor in Sweden.

Men. Taken together, we find that the significant factors for men, as seen in Table 3, are not only mixed but contradictory. Gender-role ideology is significant and in the predicted direction for dishes, laundry, and cleaning house. Education is also in the expected direction for the gender-role ideology approach for cooking and cleaning house. However, occupational prestige runs counter to the hypothesized direction for cooking and dishes. This also means that occupational prestige is in the correct direction for the relative resource hypothesis while education is the opposite of what is predicted by this hypothesis. Consistent with the timeavailability hypothesis, hours worked and spouse's occupational prestige are in the predicted 


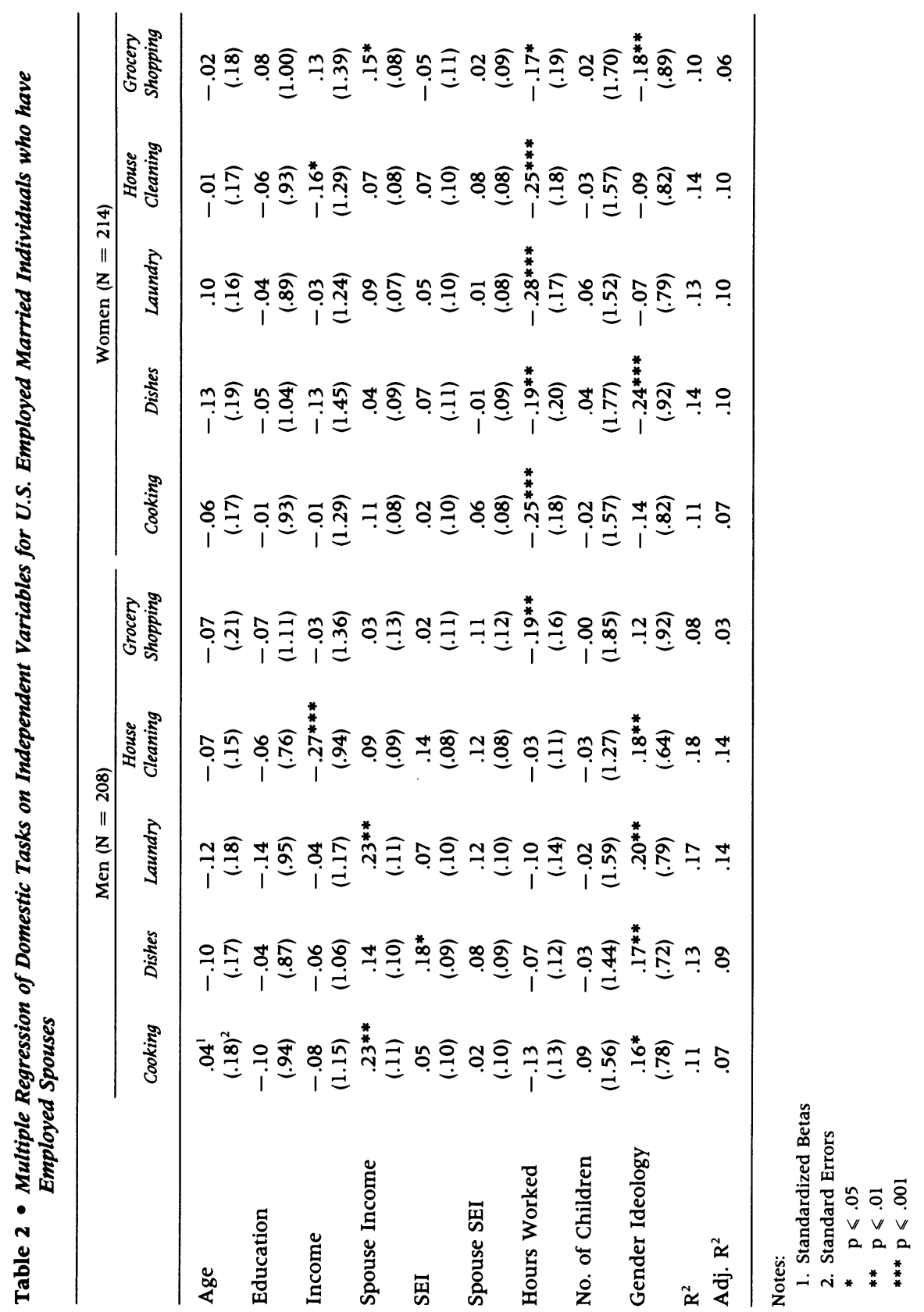


direction for laundry and housecleaning; hours worked is also related to cooking. However, the effects of income and the number of children are not significant.

High education, wife's high occupational prestige, fewer hours of work, and liberal attitudes all increase the proportion of time Swedish men spend cleaning house. As is the case for U.S. men and women, the low variance explained by these measures ( 9 percent to 16 percent) suggests that these variables are not very powerful predictors for Swedish men.

Women. As demonstrated in Table 3, few patterns can be noted across tasks or among hypotheses. The percent of spouse's relative contribution to income, representing the relative resource hypothesis, has the most consistency among Swedish women as it has a positive impact on cooking, laundry, and grocery shopping. In addition, number of children is important, resulting in more dishwashing and housecleaning. While the predictors here are fewer, the variance explained for some single indicators is relatively high, up to 21 percent.

\section{General Summary}

Little consistency exists across countries and gender groups. While gender-role ideology received some support among U.S. men, hours worked were more crucial for their female counterparts. No hypothesis received more support among Swedish men; factors for all three surfaced, in often contradictory ways. Only two factors, number of children and spouse's relative contribution to earnings, were important among Swedish women. Neither of these were significant among men. Comparing across countries, only gender-role ideology received some support for both groups of men; no other similarities were found. In all cases, the variance explained was quite low.

Two very general conclusions can be derived from these analyses. First, the approaches tested in the literature do not have much success in accounting for variance, even if some of the factors are significant. This supports our general contention that present hypotheses are too simplistic, even when combined; they do not account for the structural bases of the domestic division of labor. Second, the socialist-feminist perspective has received initial support, based on two findings: (1) different predictors of the household division of labor appear between the United States and Sweden as expected given their structural variation; and (2) there was one commonality across nations-the predicted importance of gender-role ideology among men. The significance of husbands' gender-role ideology in both countries speaks to the persistant influence of patriarchy in the United States and Sweden, despite policy changes in the latter.

\section{Combined Equations for Gender}

United States. A number of important points are immediately apparent from Table 4. First is the overwhelming importance of gender for each task. Second, only two other predictors, each representing a different hypothesis, are significant for all five tasks: spouse's relative contribution to income, which has a positive influence, and hours worked, which is negative. In addition, income is related to dishes and house cleaning. Third, the variance explained increases considerably, ranging from 37 percent to 61 percent. Part of this increase is no doubt attributable to the wider variation present in the dependent variables when men and women are combined. However, this alone cannot explain the large effect of gender and the increase in variance explained.

When these results are compared with the findings for men and women separately, the previous relationships are drastically altered, indicating that accounting for power asymmetry affects how well the hypotheses explain the allocation of household tasks. Earlier, spouse's income contribution was only important for cooking and laundry among men, and grocery 


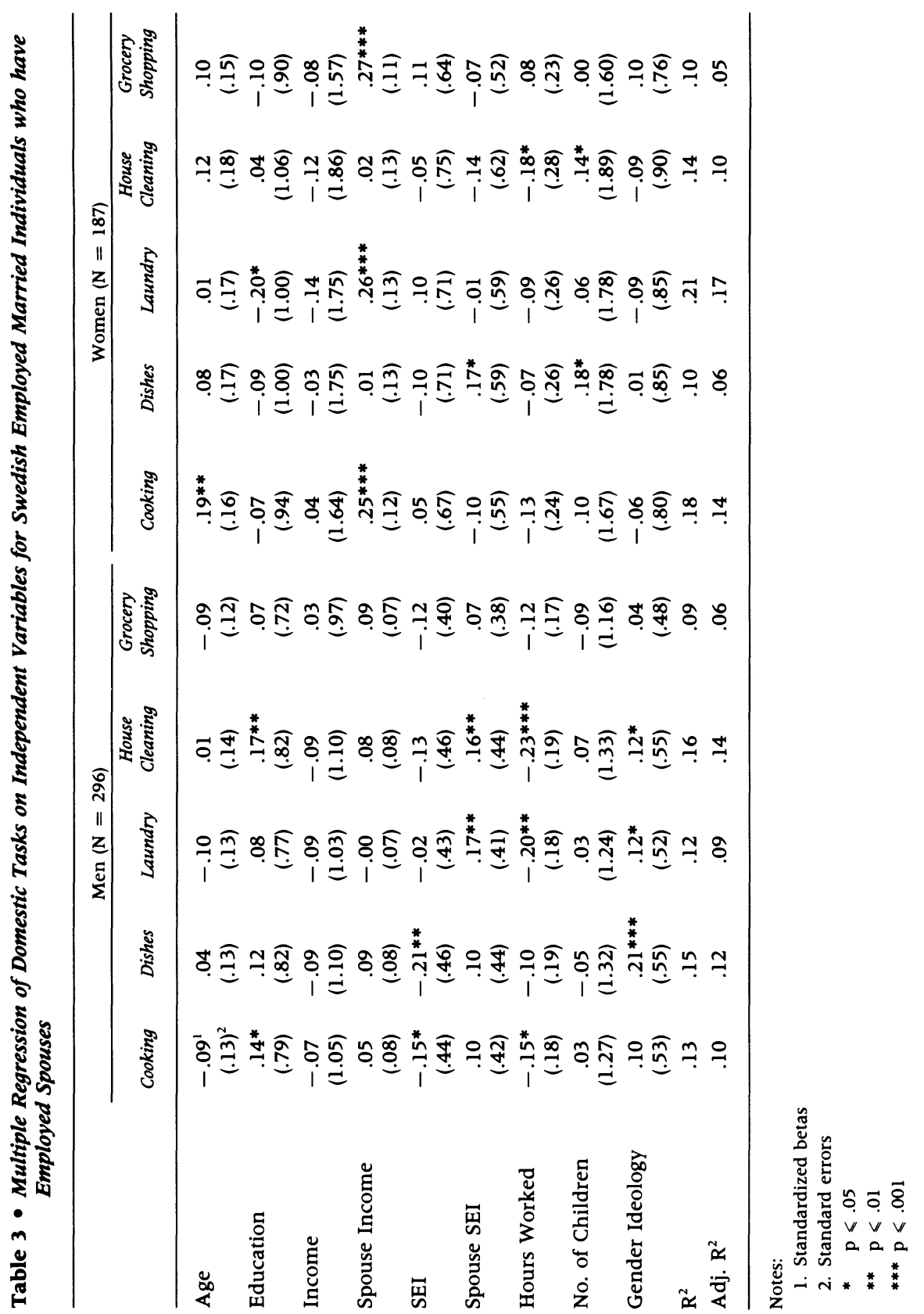




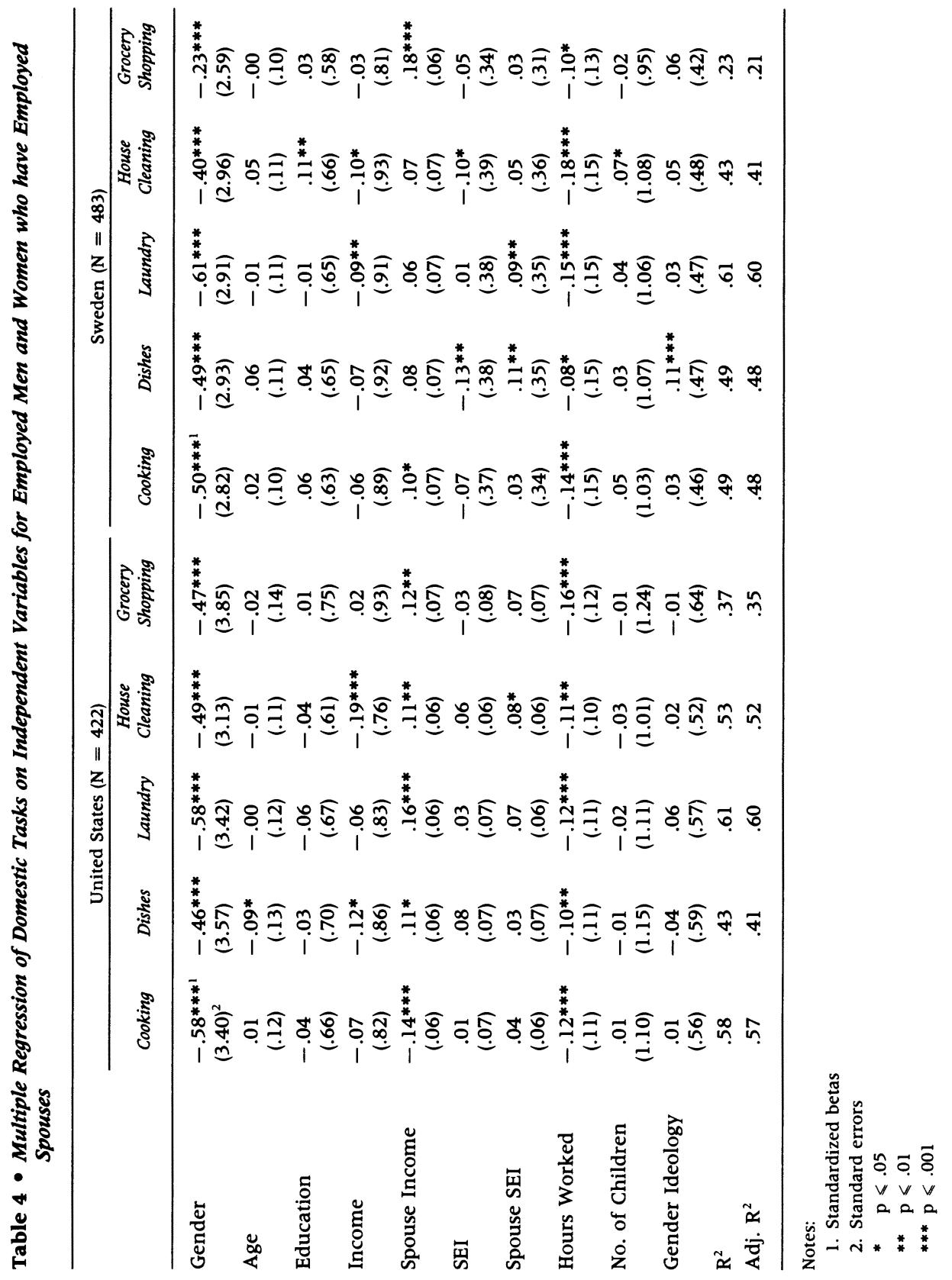


shopping among women. Hours worked had been important only for women. Both are now significant for all tasks. Most interestingly, when men and women are examined separately, gender-role ideology is important on four of five tasks for men and two tasks for women. Yet, once gender is taken into account, ideology is no longer significant, suggesting the earlier relationship was spurious.

Sweden. The results for Sweden share an important similarity with those of the United States: the strong effect of gender. Beyond this finding, Sweden shows a far more diverse pattern of influences for tasks. While hours worked are crucial across tasks, as is true of the United States, spouse's occupational prestige is important for dishes and laundry, respondent's occupation has an impact on dishes and house cleaning, and income has an influence on laundry and house cleaning. Importantly, economic power within the family, as measured by spouse's contribution to income, does not have as great an impact as in the United States, as it is significant only for groceries and cooking. Again, the variance explained is substantial, as high as 61 percent, for four of the five tasks.

Comparing these results with the earlier models is illustrative. Income was not important for either Swedish men or women in the prior equations, nor was spouse's relative contribution for men or occupational prestige for women. In addition, spouse's occupational prestige was important for laundry and house cleaning among men in the separate model; in the combined model the effects are for laundry and dishes. Finally, as was the case for the United States, the importance of gender ideology wanes when gender is introduced; now it is only significant for explaining dishwashing. Similarly, the effect of the number of children on women's performance of dishes and house cleaning disappears.

\section{Discussion}

Throughout the analyses it is apparent that different factors explain each of the various household chores. This indicates the importance of keeping tasks separate, especially when meaningful differences across predictors might be hidden otherwise. One topic for future research is the basis for this disparity, especially as this relates to power relations.

Our findings on the gender difference in time spent on household labor illustrate that the division of domestic labor does not even come close to parity. In addition, we found little significant difference between the U.S. and Sweden, despite progressive legislation in the latter country. Focusing on the persistence of the gender difference in the division of domestic labor rather than on factors accounting for the small amount of change may be more fruitful for understanding and eradicating inequality. In this regard, socialist-feminism, with its emphasis on the structural sources of gender relations, can help explain why patriarchy persists in the home. With its emphasis on both the relative autonomy and interrelations of public and private spheres, it pushes us to look beyond surface changes to explore the dynamics between patriarchy and capitalism.

Based on the socialist-feminist perspective, we formulated two general hypotheses. First, we hypothesized that there would be differences in the ability of the traditional hypotheses to account for the division of household labor in Sweden and the United States. This was based on the notion that different forms of patriarchal capitalism have varying effects on the allocation of household tasks. While we could not compare the significance of regression coefficients across equations, it appears that different factors do in fact account for the participation of both men and women in domestic labor in the two countries. First, no one hypothesis can explain the division of labor for any one group. Second, no hypothesis is a better predictor across groups; each received support in three of four equations. That is, the following proved to be important: gender-role ideology in the U.S. for both genders and in Sweden for men; 
relative resources among U.S. men and Swedes of both genders; and time availability among U.S. women and Swedish men and women. Third, regardless of which hypotheses were supported, the variance explained is low, indicating that even when combined the three hypotheses are inadequate.

Second, we hypothesized that there would be important commonalities between the United States and Sweden, as patriarchal capitalism persists in both countries, albeit in different forms. Especially illustrative are the results of the regression equations for each country which include gender in the model. First, we found that gender was an extremely potent predictor of the division of household labor. Thus, it appears none of the hypotheses adequately addresses the basis for gender inequality in the private sphere. Second, we also thought that indicators which pointed to the greater power of men, such as a husband's work hours or his gender-role ideology, might come to the forefront in the separate models across countries. However, when gender was introduced into the combined model, these influences dropped out, indicating that the earlier relationship was probably spurious.

In general, as socialist-feminism suggests that the significance of predictors is contingent upon the particular form of patriarchal capitalism, we anticipated that the different approaches would show varying patterns in the United States and Sweden. The combined equations suggest interesting differences in the constituents of marital power based on the form of patriarchal capitalism. The consistent importance of spouse's relative income contribution on the dependent variables in the United States indicates that economic power within the family is far more important in that country than in Sweden. Given the structural differences between the countries, this was expected. In Sweden, the state's provision of several services may reduce the financial aspect of power differentials within couples. In the U.S., where collective needs and minimal baseline support are not as stressed, individual economic resources will be a greater source of power. Different forms of patriarchal capitalism appear to change the form of the allocation process.

This also suggests that simply modifying past hypotheses is not enough to improve our understanding of this division. Empirically, the different results generated between the separate and combined models indicate that tests of hypotheses concerning the division of domestic labor are probably misspecified without the inclusion of gender. From a theoretical standpoint, we argue that this occurs because none of the approaches examines gender relations as an important structural source of the unequal gender division of labor. For example, while the relative resources hypothesis takes power into account, it focuses only on economic power generated in the labor market. The interaction between private and public spheres, the relative autonomy of the domestic arena, and the consequences of these for power are not considered. Similarly, recognition of power differentials might help us understand why, consistent with most past research, men's gender-role ideology appears to be more important than women's.

Education and policies geared at helping men and women share domestic duties do not mean that things will "naturally" change as men and women are given more equal opportunities to engage in domestic role-sharing. It is a mistake to assume that changes which will "allow" men to be more active mean they will be, even if we socialize boys and girls more equally. Such changes are no doubt necessary, but they are also insufficient, from a socialistfeminist standpoint, as they will only "naturally" work if the structural bases of power are equalized. If power is unequal, then despite policy changes, it will still be men's decision as to whether or not they will participate more.

Taken together, our analyses point to the importance of a further exploration of the structural bases for gender inequality in the division of domestic labor. Understanding these sources will allow for policies which may have a real impact on the distribution of power and remove the "double burden" from the shoulders of women. 


\section{References}

Acker, Joan

1989 "The Problem with Patriarchy." Sociology 23:235-240.

Berardo, Donna Hodgkins, Constance L. Shehan, and Gerald R. Leslie

1987 "A Residue of Tradition: Jobs, Careers, and Spouses' Time in Housework." Journal of Marriage and the Family 49:381-390.

Berheide, Catherine White

1984 "Women's Work in the Home: Seems Like Old Times." In Women and the Family: Two Decades of Change, ed. Beth B. Hess and Marvin B. Sussman, 37-55. New York: The Haworth Press.

Berk, Sarah Fenstermaker

1989 "Women's Unpaid Labor: Home and Community." In Women Working, 2nd edition, ed. Ann Helton Stromberg and Shirley Harkess, 287-302. Mountain View, Calif.: Mayfield.

Bielby, William T. and Denise D. Bielby

1989 "Family Ties: Balancing Commitments to Work and Family in Dual Earner Households." American Sociological Review 54:776-789.

Coleman, Marion Tolbert

1988 "The Division of Household Labor: Suggestions for Future Empirical Consideration and Theoretical Development." Journal of Family Issues 9:132-48.

Coverman, Shelley

1989 “Women's Work is Never Done: The Division of Domestic Labor." In Women: A Feminist Perspective, ed. Jo Freeman, 356-368. Mountain View, Calif.: Mayfield.

$\rightarrow 1985$ "Explaining Husbands Participation in Domestic Labor." The Sociological Quarterly 26:8197.

1983 "Gender, Domestic Labor Time, and Wage Inequality." American Sociological Review 48:623-637.

Coverman, Shelley and Joseph F. Sheley

1986 "Change in Men's Housework and Child-Care Time, 1965-1975." Journal of Marriage and the Family 48:413-422.

Farkas, George

1976 "Education, Wage Rates, and the Division of Labor Between Husband and Wife." Journal of Marriage and the Family 39:473-483.

Ferree, Myra Marx

1987 "Family and Job for Working-Class Women: Gender and Class Systems Seen from Below." In Families and Work, ed. Naomi Gerstel and Harriet Engel Gross, 289-301. Philadelphia: Temple University Press.

Finley, Nancy J.

1989 "Theories of Family Labor as Applied to Gender Differences in Caregiving for Elderly Parents." Journal of Marriage and the Family 51:79-86.

Haas, Linda

1981 "Domestic Role Sharing in Sweden." Journal of Marriage and the Family 43:957-967.

Hardesty, Constance and Janet Bokemeier

1989 "Finding Time and Making Do: Distribution of Household Labor in Nonmetropolitan Women." Journal of Marriage and the Family 51:253-287.

Hartmann, Heidi I.

1981 "The Family as the Locus of Gender, Class, and Political Struggle: The Example of Housework." Signs 6:366-394.

Hiller, Dana V. and William Philliber

1986 "The Division of Labor In Contemporary Marriage: Expectations, Perceptions, and Performance." Social Problems 33:191-201.

Hoem, Britta and Jan M. Hoem

1988 "The Swedish Family: Aspects of Contemporary Developments." Journal of Family Issues 9:397-424.

Hood, Jane

1983 Becoming a Two-Job Family. New York: Praeger. 
Kalleberg, Arne. L. and Rachel A. Rosenfeld

1990 "Work in the Family and in the Labor Market: A Cross-national, Reciprocal Analysis." Journal of Marriage and the Family 52:331-346.

Kilty, Keith M. and Virginia Richardson

1985 "The Impact of Gender on Productive and Social Activities." Journal of Sociology and Social Welfare 12:162-185.

Lengermann, Patricia M. and Jill Niebrugge-Brantley

1988 "Contemporary Feminist Theory." In Contemporary Sociological Theory, ed. George Ritzer, 282-325. New York: Alfred A. Knopf.

Mirowsky, John and Catherine E. Ross

1987 "Belief in Innate Sex Roles: Sex Stratification versus Interpersonal Influence in Marriage." Journal of Marriage and the Family 49:527-540.

Moen, Phyllis

1989 Working Parents: Transformations in Gender Roles and Public Policies in Sweden.

Madison: University of Wisconsin Press.

Perry-Jenkins, Maureen and Ann C. Crouter

1990 "Men's Provider-Role Attitudes: Implications for Household Work and Marital Satisfaction." Journal of Family Issues 11:136-156.

Pleck, Joseph H.

1984 "Men's Family Work: Three Perspectives and Some New Data." In Work and Family, ed. Patricia Voydanoff, 232-24l. Mountain View, Calif.: Mayfield.

1977 "The Work-Family Role System." Social Problems, 24:417-427.

Reskin, Barbara F. and Heidi I. Hartmann

1986 Women's Work, Men's Work: Sex Segregation on the Job. Washington, D.C.: National Academy Press.

Rexroat, Cynthia and Constance Shehan

1987 "The Family Life Cycle and Spouses' Time in Housework." Journal of Marriage and the Family 49:737-750.

Ross, Catherine E.

1987 "The Division of Labor at Home." Social Forces 65:816-833.

Seccombe, Karen

1986 "The Effects of Occupational Conditions upon the Division of Household Labor: An Application of Kohn's Theory." Journal of Marriage and the Family 48:839-848.

Shelton, Beth Anne

1990 "The Distribution of Household Tasks: Does Wife's Employment Status Make a Difference?" Journal of Family Issues 11:115-135.

Shelton, Beth Anne and Juanita Firestone

1988 "An Examination of Household Labor Time as a Factor in Composition and Treatment Effects on the Male-Female Wage Gap." Sociological Focus 21:265-278.

Sidel, Ruth

1986 Women and Children Last: The Plight of Poor Women in Affluent America. New York Viking.

Sokoloff, Natalie J.

1988 "Contributions of Marxism and Feminism to the Sociology of Women and Work." In Women Working, 2nd edition, ed. Ann Helton Stromberg and Shirley Harkess, 116-131. Mountain View, Calif.: Mayfield.

Spitze, Glenna

1988 "Women's Employment and Family Relations." Journal of Marriage and the Family 50:595-618.

1986 "The Division of Task Responsibility in U.S. Households: Longitudinal Adjustments to Change." Social Forces 64:659-701.

Voydanoff, Patricia

1988 "Women, Work and Family: Bernard's Perspective on the Past, Present and Future."

Psychology of Women Quarterly 12:269-280.

$\rightarrow$ Walby, Sylvia

1989 "Theorising Patriarchy." Sociology 23:213-234. 
Wright, Erik Olin

1986 "Class Structure and Class Consciousness: Merged Multi-national File: U.S. Survey, 1980, Sweden Survey, 1980, Norway Survey, 1982; Canada Survey, 1983." Machine-readable data file. Edited by Inter-University Consortium for Political and Social Research, Institute for Research on Poverty, University of Wisconsin (producer). Distribution by ICPSR, Ann Arbor, MI, to Virginia Polytechnic Institute and State University. 